International Journal of Agriculture, Environment and Bioresearch

Vol. 5, No. 03; 2020

ISSN: $2456-8643$

\title{
CULTIVATION TECHNOLOGY OF BARBERRY (Berberis L.) IN UZBEKISTAN
}

\author{
Erkin Turdaliyevich Berdiev \\ Doctor of Agricultural Sciences, Professor, Department of Landscape Design and Decorative Horticulture, Tashkent \\ State Agrarian University, Tashkent, Uzbekistan \\ Farkhod Makhmatmurodovich Chorshanbiev \\ Doctoral Candidate (DSc), Department of Landscape Design and Decorative Horticulture, Tashkent State Agrarian \\ University, Tashkent, Uzbekistan \\ https://doi.org/10.35410/IJAEB.2020.5503
}

\begin{abstract}
The article presents the results of scientific research on seed propagation and cultivation of seedlings of native species of barberry - oblong barberry (B. oblonga), monetary barberry (B. nummularia) and integrifolious barberry (B. integgerima), common in the flora of Uzbekistan. Sowing the oblong barberry seeds in November, collected in early September and stratified for 68 days, showed 14,9\% germination, the highest indication in spring was observed in the seeds collected in the second half of September and sown in freshly-harvested form, their germination rate was $27,4 \%$. At the same time, the gross yield of seedlings from 1 hectare of nursery amounted to 850, 0 thousand pieces, out of which 94,6\% are standard ones. Sowing the seeds of integrifolious barberry in November that were collected at the end of September, during the period of full ripeness of the fruits and stratified for 47 days, showed 42,4\% of soil germination and provided a gross yield of seedlings of 1066,6 thousand pcs/ ha out of which 93,1\% are standard seedlings. Monetary barberry seeds collected at the end of September and sown in the fall after 47 days of stratification, provided the highest rate of soil germination in spring $42,4 \%$, which ensured a gross yield of seedlings in the amount of 1483 thousand pcs/ ha and $94,7 \%$ of them are standard seedlings.
\end{abstract}

Keywords: Native species, barberry, seed viability, germination in soil, seed stratification, standard seedlings, seedling safety.

\section{INTRODUCTION}

Today, in the world a special attention is paid to the introduction of unconventional berry bushes into the culture, the fullest use of their medicinal, reclamation and decorative features, the expansion of the production of medicines of natural origin. Barberry occupies a special place among them and is a valuable plant listed in the Pharmacopoeia of the countries of Europe and the CIS due to its useful properties and the scope of practical use.

The decorative, medicinal and nutritional features of barberries make them the subject of intensive introduction, as a result of which the areas of modern habitat of many species have gone far beyond their natural ranges. Recently, Iran occupies the first place in the world in 
industrial production and export of barberry in the world: where 360 tons of barberry fruit are harvested annually and exported to 31 countries $[1,2]$.

The barberry species as a berry plant is also growing in the Russian Federation and used in a wide scope. The fruits of barberry are a valuable raw material for the food industry, the juice of berries is used as a natural harmless dye.

This plant is especially rich in the alkaloid berberine. Barberry oblong (Berberis oblonga L.) contains about 15 types of alkaloids, about $2 \%$ of berberine is contained in the root cortex. Since 1962, berberine bisulfate preparation has been recommended as a hemostatic agent. From 15 types of barberry common in the CIS countries, 20 alkaloids were identified: - berberine, berberubin, berlambine, palmitine, dehydrocoridamine, columbine, lambertine, epiberberine, iatroricine, hydrastine, berbamunine, isotetrandrine, obaberine, obamegine, oxycanthine, berbamine, chymatine, bervulcine, vulcarine and magniflorine $[4,8,11,14]$.

In addition, berries of barberry turned out to be rich in vitamins and biologically active substances, which allow us to consider the types of barberry perspective for use in medicine. In the berries of barberry of Uzbekistan, the content of vitamin C ranges from 99,8-185,0 $\mathrm{mg} \%$, vitamin B1 (thiamine) $\neg 0,095-0,294 \mathrm{mg} \%$, vitamin K (nicotinamide) $\neg$ 0,102-0,899 $\mathrm{mg} \%$ [9, $12,15]$.

Many evergreen species of barberry are decorative; they have reddish, golden-yellow leaves, which are widely used in gardening and landscape design [3].

\section{MATERIALS AND METHODS}

The local species of barberry (Berberis L.), which grows naturally in the flora of Uzbekistan, such as oblong barberry (Berberis oblonga), integrifolious barberry (Berberis integerrima) and monetary barberry (Berberis nummularia) $[6,10]$ were chosen as the object of study.

The viability of barberry seeds was determined in accordance with the requirements of the standard UzDSt 322.15.04.2009 (GOST 13056 7-68) "Seeds of trees and shrubs. Methods for determining viability" [6].

The weight of 1000 pieces of barberry seeds was identified on the basis of the requirements of the standard UzDSt 322.15.04.2009 (GOST 13056.4-67) "Methods for determining the weight of 1000 seeds" [5].

Barberry seedlings were evaluated based on the requirements of the state standard UzDSt 322.15.04.2009 (GOST 3317-90) "Seedlings of trees and shrubs" [7].

Seeds were collected from August to October in a 15-20 day period, sown and stratified. Most attention was paid to the time of sowing of autumn seeds. Sowing rate $-8 \mathrm{~g} / \mathrm{m}$. $(134 \mathrm{~kg} / \mathrm{ha})$. Sowing barberry seeds was carried out on the furrows. The distance between the furrows was 60 $\mathrm{cm}$, the height was $18-20 \mathrm{~cm}$. The seed sowing depth $-2 \mathrm{~cm}$. After sowing, the furrows were covered with a layer of sawdust in $2-3 \mathrm{~cm}$ thick. 
Vol. 5, No. 03; 2020

ISSN: $2456-8643$

\section{RESULTS AND DISCUSSION}

The fruits of barberry are diverse in both shape and color. Berries of $B$. oblonga are of dark blue and black color, 9,9 $\pm 0,04 \mathrm{~mm}$ long with 5,1 $\pm 0,04 \mathrm{~mm}$ diameter and elongated ellipsoid form. Berries of $B$. nummularia are pinkish-red in color, spherical, with a diameter of $6,3 \pm 0,04 \mathrm{~mm}$. Berries of $B$. integgerima are of dark red color, elongated cylindrical in shape, $9,0 \pm 0,13 \mathrm{~mm}$ long with $5,5 \pm 0,10 \mathrm{~mm}$ diameter.

The berries ripen in the form of a raceme, in which 8-28 pieces (B. oblonga), 24-38 pieces $(B$. nummularia), 17-24 pieces ( $B$. integgerima) of berries develop. The weight of 100 pieces of berries in $B$. oblonga is $17-23 \mathrm{~g}$, in $B$. nummularia $14-15 \mathrm{~g}$, in $B$. integgerima 16-20 grams. The berries are distributed unevenly on the branches of barberry: in the middle of the branches they are denser, while in the end parts of branches they are less and smaller form.

The length of $B$. oblonga seeds constitutes $5,7 \pm 0,04 \mathrm{~mm}$, diameter 2,4 $\pm 0,03 \mathrm{~mm}$, the weight of 1000 pieces of seeds is about 13-16 g, in dark brown color. The length of seeds of $B$. integgerima is $6,0 \pm 0,13 \mathrm{~mm}$, diameter $2,9 \pm 0,07 \mathrm{~mm}$, the weight of 1000 pieces of seeds is $15-16$ grams, color is brown. The seed length of B. nummularia is $4,3 \pm 0,07 \mathrm{~mm}$, diameter $3,2 \pm 0,13 \mathrm{~mm}$. The mass of 1000 seeds constitutes 11-12 grams, light brown in color, with a thin pink peel.

Seeds of barberry are bright, dark brown (B. oblonga) and light brown (B. nummularia, $B$. integerrima), after full maturation, they are covered with a fine reticular crust. Barberry seeds contain a direct germ, the length of which is $70-90 \%$ of the length of the seed. Duration of the period of germination of barberry seeds is 31-34 days, which shows that the seeds are different not only in morphology, but also in the length of the dormant period and the germination energy.

Barberry seeds belong to hard-germinant group due to the presence of a dormant period in them. The seed germination biology of species of the genus Berberis has been little studied. General information about the disturbance conditions of dormancy of the seeds of 7 types of barberry has been given by P. Rudolf [13], and 9 species by M.G. Nikolaeva and H.A. Alekseyeva [10].

These authors pointed to the need for autumn sowing of seeds or their long-term cold stratification. The researchers studied the structure and characteristics of the germination of the seeds of purple barberry (Berberis vulgaris var. atropyrpurea $\mathrm{RgL}$ ) and found that the husk was formed by several layers of cells of various types. The husk of the seeds is two-layered: the outer layer is dense and rather thick; while internal layer is not fused with external thin. Studies by M.G Nikolayeva and Kh.A. Alekseyeva [10] showed that the representatives of the genus Berberis L. have different periods of seed dormancy. If the North American species B. tremontii does not have a dormant period of seeds, then the seeds of B. vulgaris, B. vulgaris var. atropurpurea, B. thunbergii, B. canadensis have not deep seed dormancy. Meanwhile, other species, such as B. koreana, B. amurensis, and B.oblonga species of the endemic mountains of the Central Asia are characterized by a deep dormancy of seeds. In their opinion, the deep dormancy of $B$. oblonga and $B$. amurensis seeds is associated with the presence of the seed husk and the inability to normal growth of isolated germs. 
To eliminate the seed dormancy of B. oblonga, the authors propose a long-term cold stratification or two-stage stratification: I - during 4-5 months at a temperature of $+20 \mathrm{C}-+25$ ${ }^{\circ} \mathrm{C}$, II - during 3-4 months at a temperature of $0{ }^{\circ} \mathrm{C}-+3{ }^{\circ} \mathrm{C}$. In this case the authors argue that the presence of a warm (autumn) stage of stratification eliminates the underdevelopment of the seed germ [3].

Seeds collected from various bushes also have different germination. The barberry seeds that was freshly harvested and sown in autumn, germinate after 183-205 days, while the other seeds stored during the year and sown in the autumn germinate in 202-213 days. The preservation of the barberry seeds for germination ability is also of practical importance. Extending the shelf life reduces the viability and germination of seeds. Also, there is a decrease in the mass of 1000 pieces of seeds by 1,5-2,0 grams. After 2 years of storage, a sharp decrease in germination and seed viability is observed [2].

The first sprouts of barberry begin to appear when the average daily temperature of the soil reaches to $+80^{\circ} \mathrm{C}$. Mass seed germination occurs on April 1-13, during this period the soil temperature is $+10^{\circ} \mathrm{C}-+15^{\circ} \mathrm{C}$. An increase in soil temperature above $+10^{\circ} \mathrm{C}$ accelerates seed germination. At the end of April, when the temperature in the soil layer with seeds is $+23{ }^{\circ} \mathrm{C}+$ $24^{\circ} \mathrm{C}$, seed germination and emergence of seedlings completely cease.

Among the studied species, oblong barberry is noted as slowly growing while integrifolious and monetary barberry are fast-growing types. Seeds harvested and sown at the end of August did not germinate because their berries were unripe.

Sowing the oblong barberry seeds in November, collected in early September and stratified for 68 days, showed 14,9\% germination, the best indicator in spring was observed in the seeds collected in the second half of September and sown in freshly harvested form, their germination rate was $27,4 \%$. At the same time, the yield of seedlings from 1 hectare of the nursery made 850,0 thousand pieces and $94,6 \%$ of them are standard. Stratification within 47 days reduced seed germination, which constituted $12,1 \%$. There was a decrease in the germination capacity of all other seeds collected late or stored in dry form (Table 1).

Sowing seeds of integrifolious barberry removed from unripe fruits at the end of August also didn't provide sprouting in spring. The seeds prepared at the beginning of September and stratified for 68 days, had a high indication of sprout of 20,9\% and showed mass yield of 666,6 thous.pcs/ha seedlings. The seeds prepared at the end of September, that is, in the period of full maturation of fruits showed 31,5\% germination and gross yield of 1066,6 thous.pcs/ha seedlings, out of which 93,1\% were standard seedlings (Table 2). 
Table 1 The influence of collecting and sowing time for oblong barberry seeds (Berberis oblonga Rgl.) on the germination and yield of seedlings

\begin{tabular}{|c|c|c|c|c|c|c|c|c|c|}
\hline \multirow{2}{*}{$\begin{array}{l}\text { Seed } \\
\text { harvesting } \\
\text { time }\end{array}$} & \multirow{2}{*}{$\begin{array}{l}\text { Seed } \\
\text { sowing } \\
\text { time }\end{array}$} & \multirow{2}{*}{$\begin{array}{l}\text { State of } \\
\text { sown } \\
\text { seeds }\end{array}$} & \multirow{2}{*}{$\begin{array}{l}\text { Seed } \\
\text { viability, } \\
\%\end{array}$} & \multirow{2}{*}{$\begin{array}{l}\text { Field } \\
\text { germination } \\
\text { of seeds, \% }\end{array}$} & \multirow{2}{*}{$\begin{array}{l}\text { Seedling } \\
\text { height at } \\
\text { the end of } \\
\text { vegetation, } \\
\text { cm }\end{array}$} & \multicolumn{3}{|c|}{ Gross yield of seedlings } & \multirow{2}{*}{\begin{tabular}{|l|}
$\begin{array}{l}\text { Yield of } \\
\text { standard } \\
\text { seedlings }\end{array}$ \\
$\begin{array}{l}\text { In } \\
\text { comparison } \\
\text { with gross } \\
\text { yield, \% }\end{array}$ \\
\end{tabular}} \\
\hline & & & & & & $\begin{array}{l}1 \quad \text { m. } \\
\text { pes/run. } \\
\text { m }\end{array}$ & $\begin{array}{l}1 \text { ha. } \\
\text { thous. } \\
\text { pes./ha }\end{array}$ & $\begin{array}{l}\text { thous. } \\
\text { pes./ha }\end{array}$ & \\
\hline 22.08 & 26.08 & $\begin{array}{l}\begin{array}{l}\text { Freshly } \\
\text { collected }\end{array} \\
\end{array}$ & 17 & \multicolumn{6}{|l|}{ no sprouts } \\
\hline 5.09 & 24.11 & \begin{tabular}{|l|} 
stratif. 68 \\
days
\end{tabular} & 92 & 14,9 & $31.0 \pm 1.34$ & 29 & 483.3 & 456,7 & 94,5 \\
\hline 26.09 & 30.09 & \begin{tabular}{|l} 
Freshly \\
collected
\end{tabular} & 93 & 27,4 & $28,2 \pm 0,85$ & 51 & 850,0 & 804,1 & 94,6 \\
\hline 26.09 & 24.011 & \begin{tabular}{|l|} 
stratif. 47 \\
days
\end{tabular} & 93 & 12,9 & $36.4 \pm 1.30$ & 25 & 416.0 & 388,3 & 93,2 \\
\hline 15.09 & 29.11 & $\begin{array}{l}\text { Removed } \\
\text { from } \\
\text { dried } \\
\text { berries }\end{array}$ & 89 & 2,5 & $29.6 \pm 1.45$ & 5 & 83.3 & 80,0 & 96,1 \\
\hline 20.09 & 29.11 & \begin{tabular}{|ll} 
Dry & \\
storage & \\
for & 1 \\
year & \\
\end{tabular} & 82 & Thin sprout & & & & & \\
\hline 29.11 & 29.11 & $\begin{array}{l}\text { Freshly } \\
\text { harvested }\end{array}$ & 84 & Thin sprout & & & & & \\
\hline
\end{tabular}


Table 2.The influence of collecting and sowing time for integrifolious barberry seeds (Berberis integerrima) on the germination and the yield of seedlings

\begin{tabular}{|c|c|c|c|c|c|c|c|c|c|}
\hline \multirow[b]{2}{*}{$\begin{array}{l}\text { Seed } \\
\text { harvestin } \\
\text { g time }\end{array}$} & \multirow[b]{2}{*}{$\begin{array}{l}\text { Seed } \\
\text { sowin } \\
\text { g time }\end{array}$} & \multirow[b]{2}{*}{$\begin{array}{l}\text { State of } \\
\text { sown seeds }\end{array}$} & \multirow[b]{2}{*}{$\begin{array}{l}\text { Seed } \\
\text { viabilit } \\
\mathrm{y}, \%\end{array}$} & \multirow[b]{2}{*}{$\begin{array}{l}\text { Field } \\
\text { germi- } \\
\text { nation } \\
\text { of } \\
\text { seeds, } \\
\%\end{array}$} & \multirow[b]{2}{*}{$\begin{array}{l}\text { Seedling } \\
\text { height at } \\
\text { the end of } \\
\text { vegetation } \\
, \mathrm{cm}\end{array}$} & \multicolumn{2}{|c|}{$\begin{array}{l}\text { Gross yield of } \\
\text { seedlings }\end{array}$} & \multicolumn{2}{|c|}{$\begin{array}{l}\text { Yield of standard } \\
\text { seedlings }\end{array}$} \\
\hline & & & & & & $\begin{array}{l}1 \mathrm{~m} . \\
\mathrm{pcs} / \mathrm{run} \\
. \mathrm{m}\end{array}$ & $\begin{array}{l}1 \text { ha. } \\
\text { thous. } \\
\text { pes./ha }\end{array}$ & $\begin{array}{l}\text { thous. } \\
\text { pcs./ha }\end{array}$ & $\begin{array}{l}\text { In } \\
\text { compari } \\
\text { son } \\
\text { with } \\
\text { gross } \\
\text { yield, \% }\end{array}$ \\
\hline 23.08 & 27.08 & $\begin{array}{l}\text { Freshly } \\
\text { collected }\end{array}$ & 78 & No spro & & & & & \\
\hline 5.09 & 24.11 & $\begin{array}{ll}\text { straf. } & 68 \\
\text { days. } & \end{array}$ & 84 & 20,9 & $68,7 \pm 1,96$ & 40 & 666,6 & 615,3 & 92,3 \\
\hline 26.09 & 24.11 & $\begin{array}{ll}\text { straf. } & 47 \\
\text { days } & \end{array}$ & 86 & 31,5 & $64,8 \pm 1,94$ & 64 & 1066,6 & 993,0 & 93,1 \\
\hline
\end{tabular}

Monetary barberry seeds prepared at the end of August also did not provide emergence in spring. Seeds collected at the beginning of September which were stratified for 68 days and sown at the end of November had 30,4\% germination and ensured a mass yield of 1050 pieces / ha of seedlings.

The seeds prepared at the end of September and sown after 47 days of stratification showed the highest germination rate $-42,4 \%$, which ensured the mass yield of seedlings in the amount of 1483 thousand pieces/ha, $94,7 \%$ of them were standard seedlings (table 3 ).

Table 3 The influence of collecting and sowing time for monetary barberry seeds (Berberis. nummularia) on the germination and the yield of seedling

\begin{tabular}{|c|c|c|c|c|c|c|c|c|c|}
\hline \multirow[b]{2}{*}{$\begin{array}{l}\text { Seed } \\
\text { harvesti } \\
\text { ng time }\end{array}$} & \multirow[b]{2}{*}{$\begin{array}{l}\text { Seed } \\
\text { sowin } \\
\text { g time }\end{array}$} & \multirow[b]{2}{*}{$\begin{array}{l}\text { State of } \\
\text { sown } \\
\text { seeds }\end{array}$} & \multirow[b]{2}{*}{$\begin{array}{l}\text { Seed } \\
\text { viabil } \\
\text { ity, \% }\end{array}$} & \multirow[b]{2}{*}{$\begin{array}{l}\text { Field } \\
\text { germina } \\
\text { tion of } \\
\text { seeds, \% }\end{array}$} & \multirow[b]{2}{*}{$\begin{array}{l}\text { Seedling } \\
\text { height at } \\
\text { the end of } \\
\text { vegetation } \\
\text {, cm }\end{array}$} & \multicolumn{2}{|c|}{$\begin{array}{l}\text { Gross yield of } \\
\text { seedlings }\end{array}$} & \multicolumn{2}{|c|}{$\begin{array}{ll}\text { Yield } & \text { of } \\
\text { standard } & \\
\text { seedlings } & \\
\end{array}$} \\
\hline & & & & & & $\begin{array}{l}1 \quad \text { m. } \\
\text { pcs/ru } \\
\text { n. } \\
\text { m }\end{array}$ & $\begin{array}{l}1 \text { ha. } \\
\text { thous. } \\
\text { pes./ha }\end{array}$ & $\begin{array}{l}\text { thous. } \\
\text { pcs./h } \\
\text { a }\end{array}$ & $\begin{array}{l}\text { In } \\
\text { compar } \\
\text { ison } \\
\text { with } \\
\text { gross } \\
\text { yield, } \\
\%\end{array}$ \\
\hline 23.08 & 27.08 & $\begin{array}{l}\text { Freshly } \\
\text { collecte } \\
\text { d }\end{array}$ & 81 & No sprouts & & & & & \\
\hline 5.09 & 24.11 & stratif. & 83 & 30,4 & $75.3 \pm 2.23$ & 63 & 1050 & 977,5 & 93,1 \\
\hline
\end{tabular}


Vol. 5, No. 03; 2020

ISSN: $2456-8643$

\begin{tabular}{|l|l|l|l|l|l|l|l|l|l|}
\hline & & 68 days & & & & & & & \\
\hline 26.09 & $\begin{array}{l}24.01 \\
1\end{array}$ & $\begin{array}{l}\text { stratif. } \\
47 \text { days }\end{array}$ & 86 & 42,4 & $71.7 \pm 2.50$ & 89 & 1483 & $\begin{array}{l}1404, \\
7\end{array}$ & 94,7 \\
\hline 18.09 & 29.11 & $\begin{array}{l}\text { stratif. } \\
65 \text { days }\end{array}$ & 84 & 25,9 & $72.3 \pm 1.52$ & 51 & 850.0 & 775,2 & 91,2 \\
\hline
\end{tabular}

The dormancy period of barberry seeds is more observed in oblong and medium one in integrifolious barberry and in monetary barberry. Its physiological essence is a biological property that was formed in the process of evolution and aimed at preserving the species.

For the cultivation of two-year-old barberry seedlings in the nursery, the sum of all expenses per 1 hectare amounted to 16900,15 thousand soums/ha. And 800 thousand pieces of all grown seedlings are standard, the net cost of growing each seedling constituted 21,1 soums. Currently, the average market price of 1 piece of barberry seedling is 1000 soums, the cash flow from the sale of seedlings is 800000,0 thousand soums per hectare. It is proved that the expected net profit makes 783099,85 thousand soums.

\section{CONCLUSIONS}

It was revealed that the duration of the period of germination of barberry seeds in spring is 31-34 days. Barberry seeds collected freshly and then sown in autumn germinate after 183-205 days.

The physiological maturation of barberry seeds occurs in the second half of September. For the mass emergence of sprouts of barberry oblong in the first spring, the seeds must be collected at the end of September and immediately sown in the soil after separating them from the fruits.

In order to achieve the mass emergence of seedlings of integrifolious and monetary barberries in spring, it is necessary to stratify the seeds collected in late September for 55-60 days and sow in the soil in late autumn.

\section{REFERENCES}

[1] Berdiev E.T., Chorshanbiev F.M. Berberis L. genus biodiversity in Central Asia. "Conservation and sustainable use of biodiversity of fruit crops and wild fruit species". Proceedings of the international scientific and practical conference (23-26 August 2011). Rome, Italy, pp. 66-71, 2011.

[2] Chorshanbiyev F.M, Berdiyev E.T. Time of collecting and sowing seeds of barberry in Uzbekistan. Bulletin of Michurin state agrarian university. - Michurinsk, №4. pp. 37-41, 2016.

[3] Chorshanbiyev F.M., Kaimov A.K., Berdiyev E.T. Biology of seed germination and development of juvenile plants Berberis oblonga Rgl. Biology journal of Uzbekistan (Uzbekskiy biologicheskiy zhurnal). Tashkent, №2. pp. 21-25, 2014. 
[4] Djumabayev T.Z.. Pharmacology of barberry oblong and monetary types.: Abstract of dis. cand. med. sciences. (Ryazan state med.inst. I.P.Pavlov) -Ryazan,. 20 p. 1972

[5] GOST 13056.4-67 Seeds of trees and bushes. Methods for determining the weight of 1000 pcs of seeds. Rules for collecting samples and methods for determining sowing quality of seed. - introduced from 01.07.68. - Moscow, Publish. standards, pp.60-62, 1988.

[6] GOST 13056.7-68 Seeds of trees and bushes. Methods for determining viability. Rules for collecting samples and methods for determining sowing quality of seed. - introduced from 01.07.068. -Moscow, Publish. Standards, pp. 125-144, 1988.

[7] GOST 3317-90 Seedlings of trees and bushes: Technical conditions -introduced from 01.07.091. - Moscow, Publish. standards, 41 p, 1990.

[8] Lutfullin K.L., Karimov A.K. The influence of berberine chloride and the sum of alkaloids obtained from the root and trunk barks of barberry oblong on cardiovascular system and respiration. The problems in pharmacology and pharmacy. Works of TashGosMI, IV -edition. pp.130-131, 1976.

[9] Navruzov E.N., Shamsiadze L.A., Agamirov U.M. Biochemical evaluation of the fruits of species of Berberis genus. New and unconventional plants and perspectives of their use: Conference proceedings. Moscow, Publish. Russian university of people's friendship, book III. pp. 422-424, 2005.

[10] Nikolayeva M.G., Alekseyeva Kh.A. Biology of seed germination of species of Berberis (Berberisdaceae) genus. Botanical journal - Moscow, book 69, pp. 925-931, 1984.

[11] Nuraliyev Yu.N.. About some biological features of barberry with different racemes (Berberis heberobotrys Wolf.).: Abst. diss. cand. med. sciences (Tadjik. state.med. inst. Abu Ali Ibn Sina). Dushanbe, 19 p, 1967.

[12] Potapalskiy A.I., Petlichnaya L.I., Ivasivka S.V. Barberry and its preparations in biology and medicine. - Kiev, Naukova Dumka, $288 \mathrm{p}, 1989$.

[13] Rudolf P. Berberis L. In: Seeds of woody plants in the United States. Washington: Forest Service, pp. 247-251, 1974.

[14] Sorokopudov V.N., Deyneka V.I., Deyneka L.A., Khlebnikov V.A. Barberry as a source of biological active matter // New and unconventional plants and perspectives of their use: Conference proceedings. Moscow, book III., Publish. Russian university of people's friendship. Moscow, pp. 441-444, 2005.

[15] Umurzakova R.Z., Dumayeva M. Abnormality features of thrombocyte hemostasis of patients with chronic hepatitis and its correction with common barberry preparations. Journal of theoretical and clinical medicine. Moscow, №2, pp. 76-79, 2003. 